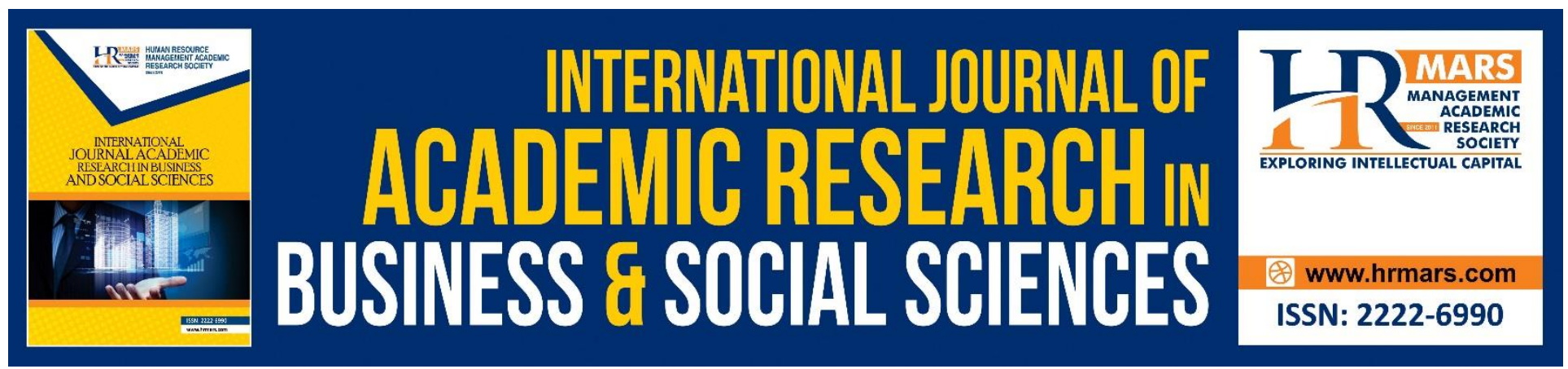

\title{
The Effect of Pay Inequality on Organizational Citizenship Behavior in Textile Sectors of Pakistan
}

\author{
Muhammad Umair Farzand, Muhammad Zia-ud-Din, Maria Rabia Haq, \\ Shahpara Rajvi
}

To Link this Article: http://dx.doi.org/10.6007/IJARBSS/v8-i7/4340

DOI: $\quad 10.6007 /$ IJARBSS/v8-i7/4340

Received: 03 July 2018, Revised: 22 July 2018, Accepted: 29 July 2018

Published Online: 04 August 2018

In-Text Citation: (Farzand, Zia-ud-Din, Haq, \& Rajvi, 2018)

To Cite this Article: Farzand, M. U., Zia-ud-Din, M., Haq, M. R., \& Rajvi, S. (2018). The Effect of Pay Inequality on Organizational Citizenship Behavior in Textile Sectors of Pakistan. International Journal of Academic Research in Business and Social Sciences, 8(7), 269-280.

\section{Copyright: (C) 2018 The Author(s)}

Published by Human Resource Management Academic Research Society (www.hrmars.com)

This article is published under the Creative Commons Attribution (CC BY 4.0) license. Anyone may reproduce, distribute, translate and create derivative works of this article (for both commercial and non-commercial purposes), subject to full attribution to the original publication and authors. The full terms of this license may be seen

at: http://creativecommons.org/licences/by/4.0/legalcode

Vol. 8, No. 7, July 2018, Pg. 269 - 280

http://hrmars.com/index.php/pages/detail/IJARBSS

JOURNAL HOMEPAGE

Full Terms \& Conditions of access and use can be found at http://hrmars.com/index.php/pages/detail/publication-ethics 


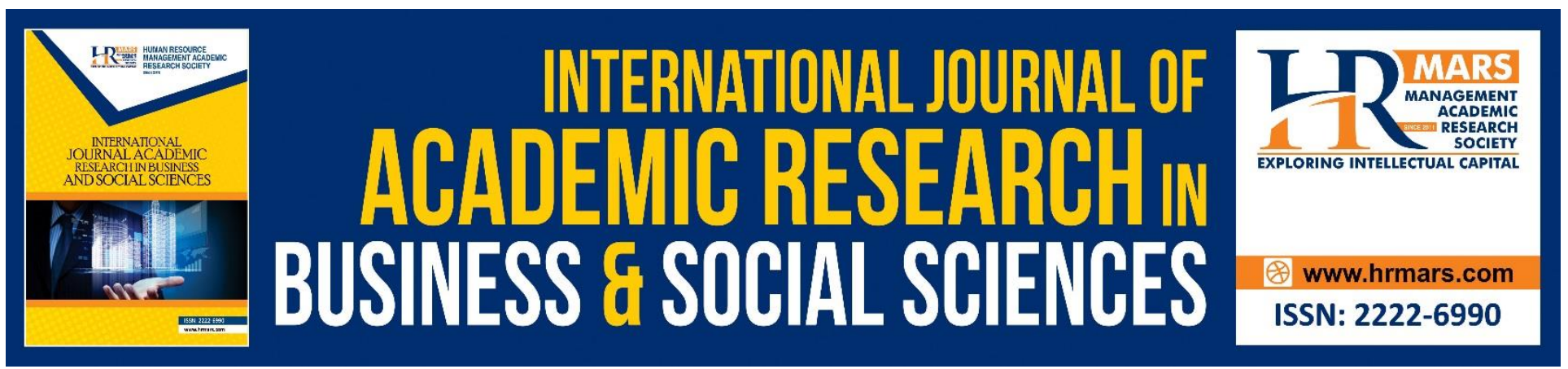

\title{
The Effect of Pay Inequality on Organizational Citizenship Behavior in Textile Sectors of Pakistan
}

\author{
Muhammad Umair Farzand \\ (Corresponding Author) \\ Mphil Scholar (Department Public Administration) \\ Government College University Faisalabad, Pakistan \\ Email: umair.farzand54@gmail.com \\ Muhammad Zia-ud-Din \\ Lecturer (Department Public Administration) \\ Government College University Faisalabad, Pakistan \\ Email: zeeyah4@hotmail.com \\ Maria Rabia Haq \\ Mphil Scholar (Department Public Administration) \\ Government College University Faisalabad, Pakistan \\ Email: Marirabiahaq@gmail.com \\ Shahpara Rajvi \\ Mphil Scholar (Department Public Administration) \\ Government College University Faisalabad, Pakistan \\ Email: shahpararajvi@gmail.com
}

\section{Abstract}

Pay inequality can cause negative employee attitude; the motivation behind this investigation is to check the variables of imbalances and how it can be control. Information is examinations through Statistical Package for the Social Sciences (SPSS) rendition 23. The respondents of this examination are managers and representatives working in material part in Faisalabad. The example measure is 150 out of which 120 is considered. The consequences of this investigation demonstrated that there is a huge connection between pay inequality and organizational citizenship behaviour. Pay inequality has positive connection with organizational citizenship behaviour. The outcomes likewise mean that representative mentality halfway direct the connection between pay disparity and organizational 
INTERNATIONAL JOURNAL OF ACADEMIC RESEARCH IN BUSINESS AND SOCIAL SCIENCES Vol. 8, No. 7, July 2018, E-ISSN: 2222-6990 @ 2018 HRMARS

citizenship behaviour. This examination likewise displays conclusion, proposals, and suggestions for future specialists.

Keywords: Pay Inequality, Organization Citizenship Behavior, Employee Attitude

\section{Introduction}

\section{Background}

Pay inequality has expanded extensively finished the most recent 15 years. (Winkelmann,2003). The distribution of pay differs significantly at some point of nations and through the years amongst superior business societies. Pay inequality are studied in sixteen nations from 1980 to 1992. because of the fact that 1980, the increases in pay inequality which have affected the USA and different superior business nations. although a few countries have maintained solid stages of pay equality, the overall trend has been closer to greater inequality of labor marketplace income in Western Europe as well as inside the USA, Canada, Japan, and Australia. Our reason in what follows is to apply systematic statistical techniques of analysis to identify the reasons of the overall trend closer to greater pay inequality for the duration from 1980 to 2000. (A. Golden and Waller stein, 2015). In America the increase of pay inequality the standard impact of economic growth on poverty alleviation. The extended economic expansion that began in 1982 had little impact on the proportion of the us population with pay beneath the poverty line. (Wallerstein,1999).

Wage inequality has increased especially within the 1990s. In global comparisons, wage inequality indicators for Turkey are generally high as compared to different countries with high common wages. even as pay inequality seems to have declined through the 1970 s, by the 1980 s this become not the case, and inside the 1990s inequality rose. The reasons noted for this deterioration encompass the poor trend in actual wages, a alternate in tax policies for the advantage of the rich, a failure of redistributive monetary policy, excessive actual interest prices and unequal training. (Elveren, Galbraith, 2001).

Pakistan's economy is described by methods for high pay inequality which took a turn for the more genuine sooner or later of the times of 1980s and mid-1990s. A profoundly stable government, built up in the 1990's presented and connected an arrangement of sound macroeconomic approaches which got high expenses of monetary increment. In 2005, Pakistan recorded the second most elevated increment rate with in the area. (JED, 2011).

Pakistan, there was high development in the many years of 1960s and 1980s and it saw low increment in 1990s. High development generally empowers inside the markdown of neediness, if it's far assigned evenhandedly and low money related development will build poverty and inequality. On the off chance that the financial increment is high yet appropriation of pay is unequal, it can in any case make commitments in developing the degree of poverty in a nation since it occurred in Pakistan inside the 1960s. In Pakistan, the inconsistencies in Pay moreover give a clarification to the unequal circulation of property' pay inequalities in Pakistan had been rising given that Nineties and the equivalent example keeps in the advanced decades (Zakri Rashidi, 2017).

\section{Problem Statement}

The issue of pay inequality is affected by how much, by every one of the components, it is deliver both negative and beneficial outcomes. The fundamental goal of any investigation ought to be to work for the welfare of the people and the general public. Pay inequality has for some time been issue with the employees in the workplace. it has devastating results on the organizational citizenship behavior and work attitude. The connection between pay inequality and organizational 
INTERNATIONAL JOURNAL OF ACADEMIC RESEARCH IN BUSINESS AND SOCIAL SCIENCES Vol. 8, No. 7, July 2018, E-ISSN: 2222-6990 @ 2018 HRMARS

citizenship behavior are not known. pay inequality happens because of number of reasons like Biasness, Un justified distribution by the head by the head, Favourism, Education, Experience and Skills. Pay inequality can harm confidence and misshape the standard, and further alienate workers from their assignments. Pay inequality reduced productivity, increase absenteeism and quitting.

\section{Significance of the Study}

The study will provide the employees with some knowledge on pay inequality and how it can be avoided. It will give the employer's a realization that the pay inequality is not useful for both the employees and the organization. At the end of this study employers would finally know why pay inequality have been a major problem to the society. The given data would guide the employees on what to do with pay inequality in the organization. In addition, this is critical for addressing to the Pay inequality at association in Pakistan. This research will expose such factors which are thought to be significant in taking out pay inequality particularly in textile organization.

\section{Scope of the Study}

The study focuses on pay inequalities among the employees of textile sector Through a process of survey analysis, the aims of this study are to: To extend current knowledge of these experiences, beliefs and meaning of pay inequalities among employees by their organization, as reported by employees and managers. To undertake a survey of textile sector employees to determine the incidence and nature of pay inequalities in the textile sector of Pakistan.

\section{Purpose of the Study}

on this context, this observe is to set up to test the effect of pay inequality on organizational citizenship behavior. additionally, this observe has great significance in particular for textile groups. It offers path to executives to enhance the level of employees work attitude and organization citizenship behavior by means of stopping pay inequalities at workplace. A quantitative research technique and configuration estimating the relationship between factors was proper for the investigation. The investigation included a study apparatus utilizing answers from questions with respect to employee's attitude in the workplace and organization citizenship behaviour to produce statistical data on pay inequality.

\section{Literature Review}

\section{Pay Inequality}

Pay inequality can fuse an extensive extent of cuts to rewards, benefits, additional minutes pay, stipends, annuities, and key pay. The general proposal is that any kind of pay inequality impacts worker mentalities particularly, basic wage diminishments can hurt soul since it is the bedrock of the work get the wage-effort bargain (Bewley, 1999; Smith, 2015). Akerlof (1982) elucidated the standard any extra effort (above essential) made by workers and any extra pay (higher than the accumulated market clearing wage rate) offered by managers can be seen as a 'blessing trade'. Thusly, any remuneration abatement can distort the standard, and further offend masters from their assignments. This is affirmed by the unquestionable extraordinary quality of pay cuts, a ponder known as descending ostensible wage unbending nature, whereby pay rises are by and large expected, and pay imbalance are seen as an unprecedented key vindictiveness. Despite in the midst of retreats, supervisors support reductions to pay cuts for the fear that remuneration cuts impel the 'best' workers to stop while as "reductions get the sadness out of the passage" (Bewley et al, 1999; 
INTERNATIONAL JOURNAL OF ACADEMIC RESEARCH IN BUSINESS AND SOCIAL SCIENCES Vol. 8, No. 7, July 2018, E-ISSN: 2222-6990 @ 2018 HRMARS

Saunders, 2017). It is along these lines supportive to enhance our comprehension of the connection between pay inequality and employee attitude. Analyst have shown that the 'felt-decency's of pay diminishments isn't simply subject to the aggregate measure of pay or pay changes, yet what's more directed by examinations with noteworthy reference social affairs (Card, 2012; Clark and Oswald, 1996; Smith, 2015). Both Keynes (1936) and Hicks $(1932,1963)$ saw that masters are so stressed over the association of their wages to those workers in near conditions that no business would set out to independently cut pay (Wootton, 1974). The importance of this evident fairness is furthermore made inside parts of general value hypothesis (Adams, 1963, 1965). Representatives survey the trade proportion of their prizes (compensation, benefits, acknowledgment) against their endeavors (aptitude level and responsibility) and after that look at this monetary record of working existence with the 'gift exchange' between similar others and their bosses. On this premise laborers change their wage-exertion deal to achieve apparent value. This has been all around upheld by observational confirmation from field tests a reduction in nominal pay was found to correspond with employee attitude and organizational citizenship behavior.

\section{Organization Citizenship Behavior}

Past investigations uncover that the atmosphere of the organization is essentially related to OCB in light of the fact that atmosphere cause observations among the employees that control their readiness of working harder and included with their work and end up excited to enlist in organizational citizenship behaviors. (Dimitriades,2007). OCB has been portrayed as individual lead that advances the destinations of the relationship by adding to its social and mental condition (Organ, 1997; Rotundo and Sackett, 2002). Research on OCB has benefitted hugely from Organ (1988) conceptualization of $\mathrm{OCB}$ as containing five unquestionable components: Altruism (e.g., helping specific individuals), Conscientiousness (e.g., going past irrelevantly required levels of cooperation), Sportsmanship (e.g., bearing the certain weights of work without grumbling), Courtesy (e.g., instructing others to keep the occasion of business related issues) and Civic Virtue (e.g., appreciating and being stressed over the life of the association). Readings on OCB yield by Polat (2007) uncovers that OCB is advantageous from numerous points of view to the association and to the worker. OCB encourages the recharging, natural introduction, asset exchange and investment funds of the association. It likewise enhances the nature of administration, expands the proficiency and the execution of the association while it lessens the expenses. Change of OCBs is essential erect for directors since they affect hierarchical results and administration quality (Gonza'lez\& Garazo,2005). OCB fundamentally decides the representatives' preparation to surrender their exertion and collaborate with the association keeping in mind the end goal to add to the profitability, worker fulfillment, consumer loyalty, and quality. Enhanced OCB speaks to workers' openness and insight to encounter changes for the effective usage of novel procedures of administration ( Jung \&Hong,2008). Organizations understood that for making due in this focused situation associations need to create worker work endeavors and for powerful working of the association representative endeavors are required that can be past the official necessities of the part.( Garg\& Rastogi,2006).Employees taking part in OCBs mirror their fulfillment with association's workplace and as a method for remunerating their association consequently (Bowling, 2010).

\section{Employee Attitude}

According to Saari \& Judge (2004) employees have attitudes and perspectives about various parts of their occupations, their professions, and their organizations. They are made out of feeling, 
INTERNATIONAL JOURNAL OF ACADEMIC RESEARCH IN BUSINESS AND SOCIAL SCIENCES Vol. 8, No. 7, July 2018, E-ISSN: 2222-6990 @ 2018 HRMARS

thought and practices. This is like what (Man ,2011) recommend and they proceed to characterize feeling as an individual being certain, negative or nonpartisan about something; they take a gander at thought as information towards things while conduct is viewed as the move made after feelings and learning. Attitude has three parts which are cognitive, affective and behavioral in nature. As indicated by (Saari et al, 2004), there are reasons of attitude change which have not yet been comprehended by specialists, these incorporate; dispositional24 impacts, social impacts and work circumstance impacts. Edgar and Geare (2013) clarifies employee responses are a typically situated reaction to representative employee attitudes, this can be seen when the employee demonstrations well beyond the ordinary obligation. Satisfied agents who feel really treated by and are trusting of the affiliation are moreover anxious to participate in rehearses that go past the average wants for their movement.

\section{Theoretical Framework}

By reviewing the literature following theoretical framework is build.

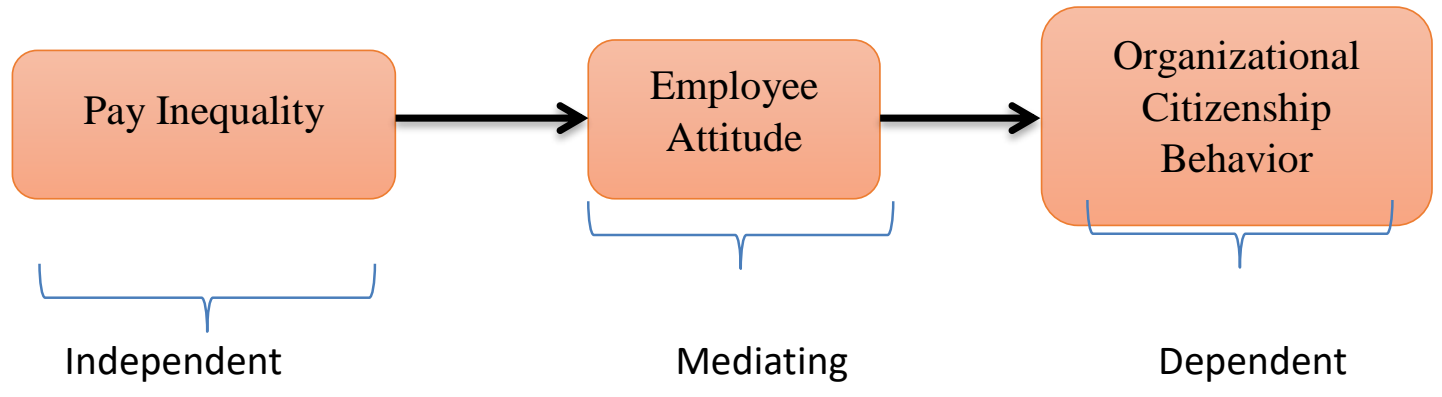

\section{Research Question}

These questions can be raised by following above theoretical framework.

What is the effect of Pay inequality on organizational citizenship behaviour within the textile sectors of Pakistan?

What is the effect of pay inequality on work attitude with in the textile sectors of Pakistan? How pay inequality is connecting with workers in textile sectors of Pakistan?

\section{Objectives of the Study}

The following are the studies objective by way of knowledge research questions.

To explore the association among pay inequality and employee's Organizational citizenship behaviour To ask the connection between pay inequality and work attitude.

To explore how is pay inequality relating with employees

\section{Hypothesis}

Keeping in view the research objective the following hypothesis can be made.

$\mathbf{H}_{1}$ : There is significant connection between Pay inequality and organizational citizenship behavior in textile sectors of Pakistan.

$\mathbf{H}_{\mathbf{2}}$ : There is a connection between Pay inequality and work attitude in textile sectors of Pakistan.

$\mathbf{H}_{3}$ : The linkage between Pay inequality and organizational citizenship behavior is moderated by work attitude in textile areas of Pakistan. 
INTERNATIONAL JOURNAL OF ACADEMIC RESEARCH IN BUSINESS AND SOCIAL SCIENCES

Vol. 8, No. 7, July 2018, E-ISSN: 2222-6990 @ 2018 HRMARS

\section{Methodology}

Test for this investigation is aggregated by means of top to bottom survey and examine through the utilization of SPSS gathered from workers and supervisors. The unit of examination of this investigation is employees working in textile organization in Faisalabad town. For statistics series, survey-based totally questionnaires are distributing among respondents of various textile businesses placed in Faisalabad. sooner than the survey added to all respondents, it's far disclosed to the respondents, so respondents fill inside the poll effectively and quite simply. The study is endeavored to check how the compensation pay inequality impact at the forefront of representative's thoughts set and they concurred that this wonder exists inside the organizations.

\section{Scales and Questionnaire}

To gauge the factors diverse scales are utilized. In segment one (demographic) the nominal and ordinal scales are utilized for initial four inquiries. The scale will use to quantify area two of the poll. The Organizational Citizenship Behavior is estimated by utilizing 42 items and embraced from (Fox, Spector, Goh, Bruursema, and Kessler, 2012). The employees' attitude is estimated by utilizing 12 item scale and pay inequality is estimated by utilizing 9 item scales. The variables will measure based on five-factor Likert scales going from 1-5 that suggests that 1 way strongly disagreed and 5 strongly agreed.

\section{DESCRIPTIVE STATISTICS}

Table-1. Demographics results.

\begin{tabular}{llll}
\hline Variable & Scale & Frequency & percentage \\
\hline Age & $20-25$ & 8 & 6.8 \\
& $26-30$ & 23 & 19.5 \\
& $31-35$ & 28 & 23.7 \\
& $36-40$ & 26 & 22.0 \\
& $41-45$ & 15 & 12.7 \\
Qualification & $46-50$ & 10 & 8.5 \\
& $51-55$ & 8 & 6.8 \\
& Intermediate & 22 & 18.6 \\
& Bachelor & 32 & 27.1 \\
Department & Master & 31 & 26.3 \\
& MS/MPhil & 29 & 24.6 \\
& PHD & 4 & 3.4 \\
& HR & 42 & 35.6 \\
& Production & 37 & 31.4 \\
& Administration & 18 & 15.3 \\
& Other mention & 21 & 17.8 \\
\hline
\end{tabular}

sample size of this research is 130 , employees operating in specific units and administrative offices of various personal textile businesses in Faisalabad. 6.8 percentage were among 20 and 25 years old, 19.5 percentage had been among 26 and 30 years, and 23.7 percent have been 31 and 35 years, 22.0 percent of 36 and 40 years old, and 12.7 percent were 41 and 45 years old and 8.5 percent were 46 and 50 years old. 18.6percent Intermediate, 27.1 percent Graduation, and 26.3 percent master,24.6 percent MPhil and 3.4 percent PhD, department wise employee's 35.6 percent 
INTERNATIONAL JOURNAL OF ACADEMIC RESEARCH IN BUSINESS AND SOCIAL SCIENCES

Vol. 8, No. 7, July 2018, E-ISSN: 2222-6990 @ 2018 HRMARS

respondent had been from HR department, 31.4 percent were from manufacturing branch, 15.3percent have been from administration department and 17.8 percent were from others.

\section{Reliability Test and Correlation}

**. Correlation is significant at the 0.01 level (2-tailed)

*. Correlation is significant at the 0.05 level (2-tailed).

\section{Reliability Test}

As per above Table Cronbach's Alpha estimation of pay inequality, Organizational citizenship behavior and employee attitude is .621,.747and .773 separately. The above Table demonstrates the estimations of Cronbach's Alpha is more noteworthy than.761, which shows the unwavering quality of information. It demonstrates that the examination instrument and its outcomes are reliable.

\section{Correlation}

Table portrays that pay inequality is positively linked with organizational citizenship behavior with a value of .573 , which is firmly significant at $1 \%$. The table likewise demonstrates that worker state of mind is decidedly connected with pay imbalance with an estimation of .181. Further organizational citizenship behavior is positively related with employee attitude with a value of .517 .

\section{Regression}

\begin{tabular}{l|llll}
\hline & A & PI & OCB & EA \\
\hline PI & .621 & 1 & & \\
OCB & .747 & $.573^{* *}$ & 1 & \\
& .773 & $.181^{* *}$ & $.517^{* *}$ & 1 \\
\hline
\end{tabular}

Model Summary

\begin{tabular}{|c|c|c|c|c|c|c|}
\hline Model & $\mathrm{R}$ & R Square & $\begin{array}{l}\text { Adjusted } \\
\text { Square }\end{array}$ & $\begin{array}{l}\text { R Std. Error of the } \\
\text { Estimate }\end{array}$ & \multicolumn{2}{|c|}{ Durbin-Watson } \\
\hline 1 & $.573^{a}$ & .399 & .393 & .42131 & \multicolumn{2}{|c|}{1.919} \\
\hline \multicolumn{7}{|c|}{ a. Predictors: (Constant), Pay inequality } \\
\hline \multicolumn{7}{|c|}{ b. Dependent Variable: Organizational citizenship behavior } \\
\hline \multicolumn{7}{|c|}{ Coefficients $^{a}$} \\
\hline \multirow[b]{3}{*}{ Model } & & \multirow{2}{*}{\multicolumn{2}{|c|}{$\begin{array}{l}\text { Unstandardized } \\
\text { Coefficients }\end{array}$}} & \multirow{2}{*}{\multicolumn{3}{|c|}{$\begin{array}{l}\text { Standardized } \\
\text { Coefficients }\end{array}$}} \\
\hline & & & & & & \\
\hline & & $\mathrm{B}$ & Std. Error & Beta & $\mathrm{t}$ & Sig. \\
\hline \multirow[t]{2}{*}{1} & (Constant) & 1.411 & .294 & & 4.797 & .000 \\
\hline & $\begin{array}{l}\text { Pay_inequalit } \\
\text { y }\end{array}$ & .636 & .084 & .573 & 7.537 & .000 \\
\hline
\end{tabular}

a. Dependent Variable: Organizational_citizenship_behaviour 
INTERNATIONAL JOURNAL OF ACADEMIC RESEARCH IN BUSINESS AND SOCIAL SCIENCES

Vol. 8, No. 7, July 2018, E-ISSN: 2222-6990 (C) 2018 HRMARS

In Table R square depicts that Pay inequality has .329\% impact on Organizational citizenship behavior which shows that a significantly impact of Pay inequality on Organizational citizenship behavior. To check the nature of correlation among the variables Durbin-Watson is calculated, which describes either correlation is positive, negative or zero. The value of Durbin Watson is 1.919 which is less than 2, it depicts that there is significant positive correlation among Pay inequality and Organizational citizenship behavior.

$$
Y=b o+b X
$$

Organizational citizenship behavior $=1.411+.573$ (Pay inequality)

This equation shows that one-unit change in pay inequality is increased the 1.984 units of. organizational citizenship behavior.

\section{Model Summary}

Std. Error of the

\begin{tabular}{llllll} 
Model & $\mathrm{R}$ & R Square & Adjusted R Square & Estimate & Sig. F Change \\
\hline 1 & $.573^{\mathrm{a}}$ & .399 & .393 & .42131 & .000 \\
2 & $.711^{\mathrm{b}}$ & .505 & .497 & .36328 & .000 \\
\hline
\end{tabular}

Predictors: (Constant), Pay_inequality

Predictors: (Constant), Pay_inequality, Employee_attitude

Coefficients $^{\mathrm{a}}$

\begin{tabular}{|c|c|c|c|c|c|c|}
\hline \multirow[b]{2}{*}{ Model } & & \multicolumn{2}{|c|}{ Unstandardized Coefficients } & \multicolumn{2}{|l|}{$\begin{array}{l}\text { Standardized } \\
\text { Coefficients }\end{array}$} & \multirow[b]{2}{*}{ Sig. } \\
\hline & & $\mathrm{B}$ & Std. Error & Beta & $\mathrm{t}$ & \\
\hline 1 & (Constant) & 1.411 & .294 & & 4.797 & .000 \\
\hline \multirow{4}{*}{2} & Pay inequality & .636 & .084 & .573 & 7.537 & .000 \\
\hline & (Constant) & 1.602 & .316 & & 6.638 & .001 \\
\hline & Pay inequality & .550 & .074 & .496 & 7.437 & .000 \\
\hline & Work attitude & .414 & .065 & .427 & 6.405 & .000 \\
\hline
\end{tabular}

a. Dependent Variable: Organizational citizenship behaviour

In Table R square depicts that Pay inequality and with mediator Work attitude has $50.5 \%$ impact on Organizational citizenship behavior which shows that a significantly impact of Pay inequality on Organizational citizenship behavior. To check the nature of correlation among the variables Durbin-Watson is calculated, which describes either correlation is positive, negative or zero. 
INTERNATIONAL JOURNAL OF ACADEMIC RESEARCH IN BUSINESS AND SOCIAL SCIENCES

Vol. 8, No. 7, July 2018, E-ISSN: 2222-6990 @ 2018 HRMARS

The value of Durbin Watson is 1.997 which is less than 2, it depicts that there is significant positive correlation among Pay inequality and Organizational citizenship behavior.

$\mathrm{Y}=\mathrm{bo}+\mathrm{bX}$

Organizational citizenship behavior $=1.602+.711$ (Pay inequality and Work attitude)

This equation shows that one-unit change in pay inequality is increased the 2.313 units of. organizational citizenship behavior.

\section{Recommendation}

It is important to reduce the pay inequalities that employees understand, by using developing truthful pay plan at administrative center. it's far recommended that the textile sectors need to have a look at employee's mind-set or behaviors towards their employer in the different units to arrange the reason why employees receive unfair pay. Have effective and fair pay programmers for all the employees to set up a positive employee's attitude towards their work and organizational citizenship behavior.

\section{Implication of the Study}

No research is without some implication. This study will help employer or manager to understand the employee's positive attitude towards their work and can help employees to make citizenship relation with the organization. In this way employers will realize the importance of fair pay plans which is very effective in satisfying employees and enhancing their citizenship relation with the organization. Managers should reexamine their pay and compensation procedures to reduce the pay inequalities at work. Findings from this research have critical implications for employees. Inequalities that's visible at work must be checked and managed seeing that it can cause extra critical conflicts.

\section{Study Limitations}

The present examination exhibited that reasonable Pay is imperative in improving workers' citizenship behavior and in addition employee attitude. Be that as it may, the examination isn't without sure limits. One of the limits is that in this exploration, we checked the effect of pay inequalities on employee's attitudes and organizational citizenship behavior which has been affirmed utilizing an example of respondents from managers and workers of textile associations in a single significant material city Faisalabad, Pakistan. Additionally, studies can be reached out in various urban communities to check the general impact of pay inequality crosswise over nation.

\section{Conclusion}

The current findings indicate that pay inequality can cause negative employee attitude. This study has identified a significant positive correlation between pay inequality and organizational citizenship behavior. On the other hand, and perhaps more importantly, this investigation has added to the examination literature by distinguishing employee attitude as a mediator affecting organizational citizenship behavior. Precisely, the study shows that pay inequality can weakens the employee's citizenship behavior with their organization.

\section{References}

Adams, J. S. (1963), "Toward an understanding of inequity", Journal of Abnormal and Social Psychology, Vol.67, pp. 422-436. 
INTERNATIONAL JOURNAL OF ACADEMIC RESEARCH IN BUSINESS AND SOCIAL SCIENCES

Vol. 8, No. 7, July 2018, E-ISSN: 2222-6990 @ 2018 HRMARS

Adams, J.S. (1965), "Inequity in Social Exchange", in (L. Berkowitz, Ed.) Advances in Experimental Social Psychology, Vol. 2, pp. 267-299.

Adem Y. Elveren1 James K. Galbraith (1980-2001) - Pay Inequality in Turkey in the

Neo-Liberal Era; The European Journal of Comparative Economics Vol. 6, n. 2, pp. 177.

Akerlof, G. (1982), "Labor contracts as partial gift exchange", The Quarterly Journal of Economics, Vol. XCVII No. 4, pp.543-569.

Bewley, T. F. (1999), Why wages don't fall during a recession, Cambridge: Harvard University Press Bewley.

Bewley, T. F. (2005), "Fairness, reciprocity and wage rigidity", in H. Gintis, S. Bowles, R. Boyd, and E. Fehr (Eds), Moral sentiments and material interests: the foundations of cooperation in economic life, Cambridge: MIT Press, pp. 303-338.

Card, D., Mas, A., Moretti, E. and Saez, E. (2012), "Inequality at work: The effect of peer salaries on job satisfaction", The American Economic Review, Vol.102 No.6, pp.2981-3003.

Clark, A.E. and Oswald, A.J. (1996), "Satisfaction and comparison income", Journal of public economics, Vol. 61 No.3, pp.359.

Edgar. F \& Geare. A, 2013. An employee-centred analysis: professionals' experiences and reactions to $\mathrm{hrm}$. published online: 20 June 2013 the international journal of human resource management.

Hicks, J. (1932 and 1963), The Theory of Wages, MacMillan

Keynes, J. M. (1936), The general theory of interest, employment and money. London: Macmillan. Saari.L.M \& Judge. T.A 2004. employee attitudes and job satisfaction.

Saunders, M. (2017) [External MPC Member, Bank of England]: The labour market, Speech to Resolution Foundation, London 13 January 2017.

Smith, J. C. (2015), "Pay Growth, Fairness, and Job Satisfaction: Implications for Nominal and Real Wage Rigidity", The Scandinavian Journal of Economics, Vol. 117 No.3, pp.852877.

Wootton, B., (1974). Fair pay, relativities and a policy for incomes, by the Baroness Wootton of Abinger (Vol. 20). University of Southampton. 